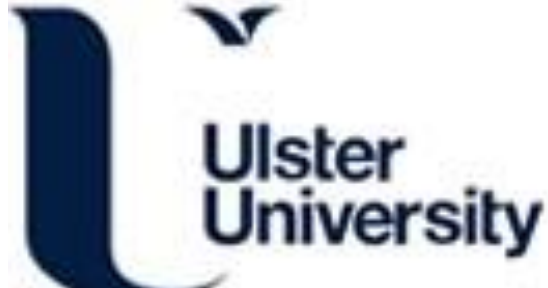

\section{Embedding technology in translation teaching:evaluative considerations for courseware integration}

Barr, D. (2012). Embedding technology in translation teaching:evaluative considerations for courseware

integration. Computer Assisted Language Learning, 26(1), 1-16. https://doi.org/10.1080/09588221.2012.658406

Link to publication record in Ulster University Research Portal

\section{Published in:}

Computer Assisted Language Learning

Publication Status:

Published (in print/issue): 02/03/2012

DOI:

10.1080/09588221.2012.658406

\section{Document Version}

Publisher's PDF, also known as Version of record

\section{General rights}

Copyright for the publications made accessible via Ulster University's Research Portal is retained by the author(s) and / or other copyright owners and it is a condition of accessing these publications that users recognise and abide by the legal requirements associated with these rights.

\section{Take down policy}

The Research Portal is Ulster University's institutional repository that provides access to Ulster's research outputs. Every effort has been made to ensure that content in the Research Portal does not infringe any person's rights, or applicable UK laws. If you discover content in the Research Portal that you believe breaches copyright or violates any law, please contact pure-support@ulster.ac.uk. 
This article was downloaded by: [University of Ulster at Coleraine]

On: 10 May 2012, At: 06:24

Publisher: Routledge

Informa Ltd Registered in England and Wales Registered Number: 1072954 Registered

office: Mortimer House, 37-41 Mortimer Street, London W1T 3J H, UK

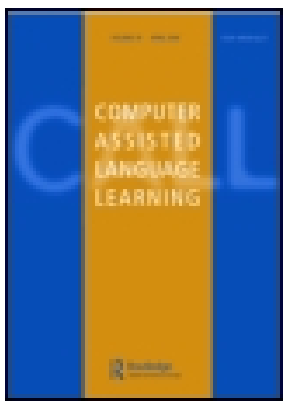

\section{Computer Assisted Language Learning}

Publication details, including instructions for authors and subscription information:

http:// www. tandfonline.com/loi/ ncal20

\section{Embedding technology in translation teaching: evaluative considerations for courseware integration}

David Barr ${ }^{a}$

${ }^{a}$ Centre for Excellence in Multimedia Language Learning, University of Ulster, Co Londonderry, Northern Ireland

Available online: 02 Mar 2012

To cite this article: David Barr (2012): Embedding technology in translation teaching: evaluative considerations for courseware integration, Computer Assisted Language Learning, DOI: 10. 1080/ 09588221.2012.658406

To link to this article: http:// dx.doi.org/ 10.1080/ 09588221.2012.658406

\section{iFirst}

\section{PLEASE SCROLL DOWN FOR ARTICLE}

Full terms and conditions of use: http://www.tandfonline.com/page/terms-andconditions

This article may be used for research, teaching, and private study purposes. Any substantial or systematic reproduction, redistribution, reselling, loan, sub-licensing, systematic supply, or distribution in any form to anyone is expressly forbidden.

The publisher does not give any warranty express or implied or make any representation that the contents will be complete or accurate or up to date. The accuracy of any instructions, formulae, and drug doses should be independently verified with primary sources. The publisher shall not be liable for any loss, actions, claims, proceedings, demand, or costs or damages whatsoever or howsoever caused arising directly or indirectly in connection with or arising out of the use of this material. 


\title{
Embedding technology in translation teaching: evaluative considerations for courseware integration
}

\author{
David Barr* \\ Centre for Excellence in Multimedia Language Learning, University of Ulster, Co Londonderry, \\ Northern Ireland
}

\begin{abstract}
This article shall discuss a number of factors to be considered in the process of integrating computer technology into the student language learning experience. It examines research on student attitudes and the factors that affect student engagement with the technology before looking at the experiences of a project undertaken at the University of Ulster aimed at integrating computer technology into the delivery of undergraduate classes on French translation. By drawing on the experience and examples in the project, this article shall conclude by outlining a number of issues to be considered in the integration of multimedia technologies in the delivery of language learning. This will include a range of considerations, such as student attitudes and level of comfort as well as pedagogical concerns.
\end{abstract}

Keywords: integration; attitudes; motivation

\section{Introduction}

There are many factors involved in the process of integrating computer technology into the student learning experience. This study seeks to evaluate the qualitative impact of CALL to the learner. These studies are not new: in 1988, Hubbard developed an evaluation framework that identified five criteria to be considered when evaluating the impact of software: operational description, learner fit, teacher fit, appropriateness and implementation scheme (Hubbard, 1988, p. 54). Dunkel and Chapelle each present six additional criteria for evaluating CALL software (Leakey, 2011, pp. 93-105).

The studies are supported by Barr's work on student learning that established a number of factors to be considered in order to embed computer-based language learning into the student learning experience (Barr, 2004, pp. 195-218). According to Barr's taxonomy, there were three main factors that influenced student attitudes towards the use of computer technology in language learning: these were grouped into technical and pedagogical and psychological considerations. These factors relate to technical concerns such as the processing capabilities of PCs and printers, considerations that cannot easily be seen such as student motivation, level of comfort, familiarity with the technology and curriculum impact.

\footnotetext{
*Email: jd.barr@ulster.ac.uk 
Given the ever-changing nature of computer technology, it seems likely that the types of technical issues identified above will have changed considerably and some of those issues, such as the use of dial-up connections, will have all but disappeared in an area of high-speed mobile broadband networks that were certainly not available at the time of the earlier study. Improvements to the reliability and speed of computers do not, however, necessarily mean that computers can easily be embedded into the student learning experience. Bennett, Manton, and Kervin (2007, p. 783) discovered that even though computer technology is becoming increasingly embedded into the lives of students and young people, its adoption is not uniform. They conclude that there are no clear reasons for this, such as disaffection with technology. Their findings highlight the importance of a discussion on the range of factors that continue to affect the embedding of technology in the learning experience. The relevance of these factors is supported by recent research. Neumeier and Stracke, for example, highlight the importance that student attitudes play in the process of integrating computer technology into their language learning processes and point towards the need for further research into student attitudes (Neumeier, 2005, p. 163; Stracke, 2007, p. 76).

The research outlined above indicates a range of factors to be considered when evaluating the effectiveness of the CALL. While each one presents a different set of criteria, all seem to identify three common trends: (1) the need for the software to make a demonstrable difference to the learning experience by fitting the learner's expectations; (2) the importance of practicality, in other words, the software needs to help, rather than hinder the learning and teaching process and (3) the motivational effect of CALL and the impact that it has on the use of the software. This present study proposes to examine the impact of these factors on student use of CALL in the roll-out of a project, carried out at the University of Ulster. It shall then examine the impact of these considerations in a project that sought to integrate computer technology into the teaching of French translation at the University of Ulster. It will conclude by examining a series of steps aimed at tackling these issues in order to enhance the embedding of multimedia language learning materials in the teaching and learning environment.

\section{Learner expectations}

Research in the area of human-computer interaction shows that the nature of the relationship between both parties has changed considerably, with less emphasis on the computer interface and more on the human use of the technology (Fischer, 2001, p. 67). It follows from this, therefore, that different users will achieve differing levels of proficiency in the use of computer technology. This has led to what Prensky defines as the birth of digital natives. In other words, the group of computer users who have spent their entire lives surrounded by computers, mobile telephones and all those technologies that are synonymous with the digital age (Prensky, 2001, p. 1). This term may reasonably be applied to students of the present day (Cuban, 2001, p. 163). This does not mean, however, that all students use computer technology effectively to enhance their experience of language. According to Gillespie (2008, p. 12), the move to digital natives has not yet happened in language learning. This would suggest that, whereas students may be increasingly computer literate and use a range of digital technologies on a daily basis, they do not necessarily use the 
technology instinctively in the process of learning a language. A number of reasons could explain this:

\section{Training}

The use of digital technology in language learning has continued to progress at breath-taking speed. The increased interactivity of the Web and the use of mobile technologies are some such examples. Nevertheless, students are not always aware of the possible uses of technology in language learning. Niño (2009, p. 253) discovered that many of those involved in her project to use machine translation in foreign language learning would have liked more training in the advanced elements of this area. In other words, students need to feel they are able to use the technologies if they are to exploit them effectively. Winke and Goertler (2008) made a similar finding in their research, concluding that many students do not have the skills necessary to engage with computer-based language learning materials because they represent a more complex level of engagement than they are used to when checking e-mail or using social networking software.

\section{Comfort}

The extent to which users feel comfortable using technology is another factor that contributes to their successful integration into the learning and teaching environment. Conole's recent research into the attitudes of learners towards e-learning showed that students tend to use technologies that they are familiar with and, by extension, that they probably find easiest to use (Conole, 2008, p. 135). The value of "comfortable" technologies was also highlighted in a recent survey conducted at the University of Ulster's Centre for Excellence in Multimedia Language Learning supported this principle. That survey received responses from 147 academics throughout the UK and one of the key findings of the research showed that there was an obvious divide in the use of technology for language teaching (Toner, Barr, Carvalho Martins, \& Wright, 2008 , p. 6). Over half of the respondents confirmed that they used computers, audio cassette and VCR on a regular basis for their teaching. This compared to very low use of such technologies as MP3 players and PDAs (4.5\% of respondents, for example, confirmed that they used MP3 players on a regular basis within their teaching). These results show a clear division in the use of relatively new technologies and more wellestablished ones. Although that survey was conducted among staff rather than among students, it highlights the importance of familiarity with the technology, regardless of the user. In the survey, it is likely that staff users were more familiar with technologies such as PCs and video and tape recorders and therefore have probably explored the possibility for using these in their teaching more thoroughly. In other words, if users are not comfortable with the technologies, it is unlikely that they will engage with them.

\section{Practicality of fit}

Even if the above factors are addressed, there is no guarantee that the technology will be used by staff and students for teaching and learning. Conole mentions the importance of "personal appropriation of tools" as having an impact on the adoption of technology in teaching and learning (Conole, 2008, p. 137). A number of factors will influence how the technology is appropriated. 


\section{Pragmatic use}

This means that if students see the technology as addressing a particular need in their learning, they are more likely to engage with it. A recent investigation discovered that there tends to be a limit of between 60 and 90 minutes working in front of computers, after which time they tend to reject the medium because of the difficulty working on screen (Stracke, 2007, p. 75). Equally, according to Fry, Ketteridge, and Marshall (1999, p. 30) students tend to be strategic learners and organise their learning specifically to obtain a high grade. This strategic adoption of technologies by students might also be considered one of the reasons why staff using particular technologies. According to the survey on the use of multimedia in language learning (Toner et al., 2008, p. 6), e-mail was most commonly used to perform tasks like communicating with students $(93.5 \%)$, while the Web was hardly used by any of the respondents for this purpose $(10.3 \%)$. One of the most obvious reasons for this difference is likely to be that students view e-mail as the main way of communicating with their tutors outside class, while they see the Web as either a research tool or view Web 2.0 technologies such as blogs and social networking sites, as tools they only use with their friends (see Mazer, Murphy, \& Simonds, 2007, p. 14). These findings point towards a strategy adoption of technology and support work in the area of human-computer interface. Fischer (2001, p. 70), for example, explains that the key aspect of human-computer interaction is the delivery of information at the right time and in the right way. In other words, the technology needs to fit the learning environment it is being used for. If, for example, a distance-learning environment would use e-mail, instant chat and other tools in ways that would not seem appropriate in face-to-face classroom situations.

\section{Course fit}

Gillespie and Barr's (2002, p. 131) taxonomy of staff users of multimedia technologies found that staff fitted into three broad categories of users: radicals, pragmatists and resistants. Their investigation suggested that most staff is pragmatists - they will use the technology when it makes a difference to their teaching. A similar finding was reached by Barr in relation to student use of technology. That research showed that, even though there was no quantifiablymeasurable benefit for using computer technology to enhance their language learning, students chose to engage with the language learning software because they were aware of benefits such as enhanced feedback (Barr, 2008, p. 110). It would follow from this, therefore, that students too might be considered as pragmatic adopters of technology.

\section{Motivation}

According to Newstead and Hoskins (1999, p. 73), motivation is central to the learning experience and, therefore contributes to effective learning. In the area of language learning, computer technology has been used to motivate learners. SteppGreany (2002, p. 166), for example, highlights the affective benefits to the learners, which can have a positive influence on the attitudes of students using computer technologies in their learning. De los Arcos, Coleman, and Hampel (2009, p. 14) discovered that the emotions felt by learners had an impact on their use of audiographic conferencing software in their learning. Barr discovered that using 
computer software to teach French grammar proved to be highly motivating for students and this had a positive impact on their level of engagement with the technology, even though using the technology did not produce quantifiably obvious benefits to the learners (Barr, 2008, p. 112). A similar conclusion was reached by Ushida (2005, p. 67) in her research into student attitudes towards an online French and Spanish course. Furthermore, when students feel supported in their learning, this is likely to motivate them further to learn (Dörnyei, 2001) These studies support the argument that if students feel the technology is having a benefit on their learning, they are more likely to engage with it, therefore allowing for the technology to be integrated more seamlessly into the learning experience. This argument is also supported by Ryan and Deci (2000, p. 74) whose study on self-determination theory highlights the importance of content relevance to the process of student motivation.

All of these issues clearly have an impact of how effectively technology can be used in language teaching. In order to contextualise these issues, this article will look at the experiences of a recent project undertaken at the University of Ulster to integrate computer technology into teaching French translation.

\section{Computer-based translation: an example of student reaction}

In 2005, The University of Ulster established its Centre for Excellence in Multimedia Language Learning (CEMLL) as part of the UK-wide Centres for Excellence in Teaching and Learning (CETL) initiative. This scheme provided funding for a fiveyear period for investment in staff (including a technician and language technologists) and equipment. As part of the five-year initiative, the CEMLL undertook a number of different projects investigating the use of multimedia technologies in teaching and learning. These projects would be led by a language technologist who would be a lecturer in the subject area but would have a reduced teaching load to allow time for materials development. One such project was an investigation into teaching translation.

\section{Background}

Using translation to teach modern languages is a long-established pedagogical principle: the grammar-translation method of teaching was long used as a direct method for teaching language in the UK; however the early 1960s saw an increased focus on communicative language teaching, whereby the target language was seen as a facilitator of communication (Hawkins, 1981, p. 8; Scinicariello, 1997, p. 189). The field of translation teaching has evolved since then. The 1972 Holmes map of translation studies divides the study of translation into two categories: pure and applied (Munday, 2001, p. 10). The former largely relates to the teaching of the theoretical phenomenon of translation, while the second focuses on the application of translation methods. The former is seen as facilitating the latter in order to achieve what Pym identifies as the key aspect of translation teaching - the successful union of two key skills: firstly, the ability to generate a target text series of more than one viable term for a source text and secondly, the ability to select only a target text from this series and to propose this as a replacement of source text (Pym, 1992, p. 281).

Using computer technology to teach the application of translation is not a new concept. One of the earliest initiatives was the CTI-funded TransIT Tiger, which 
gave students access to model translations that can be used to provide invaluable tips on translation technique (Talbot, 1996, pp. 20-23).

Equally, it is a long-established principle of CALL design that courseware needs to be integrated into language teaching in an appropriate context and not as standalone creations (see Levy, 1997, p. 24; Jones, 1986, p. 171). This clearly highlights the importance of the learning context: technologies offer different strengths and weaknesses and designing an environment that can capitalise on the pedagogical benefits of a range of technologies appears to be an effective principle. It was in this context that the CEMLL team developed a translation project that used a range of multimedia technologies.

The project was undertaken by a group of 23 year two undergraduate students of French at the University of Ulster's Coleraine campus in semester 2 (February-June) of the 2006/2007 academic year. All the students were enrolled on dedicated translation module based on Holmes map of translation studies, aimed at providing the students with an introduction to translation theory and applied experience in translation through the study of a range of practical translation tasks from English into French and from French into English. In each class, students would examine aspects of translation theory through the discussion of register, approximation and comparison and apply these to practical translation tasks. Texts were chosen from a range of sources, including newspapers such as Liberation and The Observer and more informal publications such as BBC News and Yahoo Actualités as well as literary works, including Albert Camus' L'Étranger. The purpose of this was to give students an exposure to a variety of linguistic registers and target language audiences. These students were half way through their four-year language degree. All these students had studied French since high school in the UK and half of the cohort studied a two-language degree (either studying German or Spanish alongside French). It could, therefore, be argued that the group was of clear mixed ability with half of the group studying a second foreign language and the other half only studying one language, with the resultant ability to concentrate efforts on one language.

Furthermore, all the students had studied translation as part their University degree in year 1 and for the early part of year 2, as well as throughout high school. They were, therefore, very familiar with the use of translation tasks in language teaching. The use of a mixed ability group, may seem problematic in terms of reliability of data, although recent research has identified that the link between student ability and the evaluation of CALL is not clear cut (Leakey, 2011, p. 241). Furthermore, although familiarity with the learning activity may skew the results of project because it may influence student attitudes, all students in this study had the same background in translation and makes it possible to identify patterns of use or attitude with greater ease than would be possible if some students were less familiar with the activity.

The project saw the delivery of translation classes using a range of multimedia tools and resources. Traditionally, these classes are taught in seminar rooms, although the classes for the purposes of this study were taught in one of the University's multimedia language learning classrooms, operating a range of CALL software, such as online dictionaries and grammar materials. Furthermore, as the students were introduced to the practice of consulting related articles and texts to help them complete translations, web access became an essential part of the teaching and learning experience, which would have been made more difficult if the classes 
had not been taught in a multimedia environment. The environment was designed to provide students with access to a range of viable terms for their source text which, as we saw earlier, is a key aspect of translation teaching. This room used for the delivery of classes was also equipped with 24 networked PCs linked to a central teacher console using multimedia management software (Robotel, supplied by Activa Solutions). The lab offered a number of key functions to the teacher and students, these were:

(1) A dedicated control console. With this facility, the teacher could monitor individual student performance by viewing their screens and, where necessary, take keyboard control to provide support to individuals or groups without interrupting the others in the class.

(2) Screen broadcast facility. This allowed the teacher to display the contents of student screens to others in the classroom. This feature allowed the teacher to display translations completed by different groups using the wiki on all student workstations to facilitate group discussion and feedback.

In the laboratory, two main translation activities were undertaken during the semester:

(1) Wikis. One of the main drawbacks of teaching students in front of computer screens is the danger of isolation (Gillespie \& McKee, 1999, p. 42). Computer screens can form a barrier between students and teachers, allowing some to "hide" behind their screen and therefore not participate in the class. Although this can offer comfort and reassurance for timid students, who feel embarrassed about participating in class (Stepp-Greany, 2002, p. 165), it can be particularly problematic in classes such as translation, where interactivity is an essential part of the teaching and learning experience. In order to foster interaction in a computer lab environment, a web-based wiki was used to teach translation in the computer lab. This consisted of weekly translation texts being posted on a password-protected area of a wiki. Registered users (namely the students registered in the translation module) were given access rights to translate parts of the text using the "comment" feature of the wiki. When the students arrived in class, they would access the translation text and then, in groups of three (these groups remained the same throughout the project), would translate a designated part of the text (such as a paragraph) and post it to the wiki so that all their colleagues could see what they had done. The end result would be a completed translation, which would then be discussed in the latter part of the class and changes suggested. At this stage in the class, the tutor would release a fair copy of the translation into the wiki so that students could compare their work to that of the fair copy. Since all students were required to login to the wiki, the tutor could keep track of students' performance and identify students who had completed the work and those who had not. Furthermore, the work from each week was available for students as an archive which they could use for revision purposes. See Figure 1 for an example of how the wiki was used. 


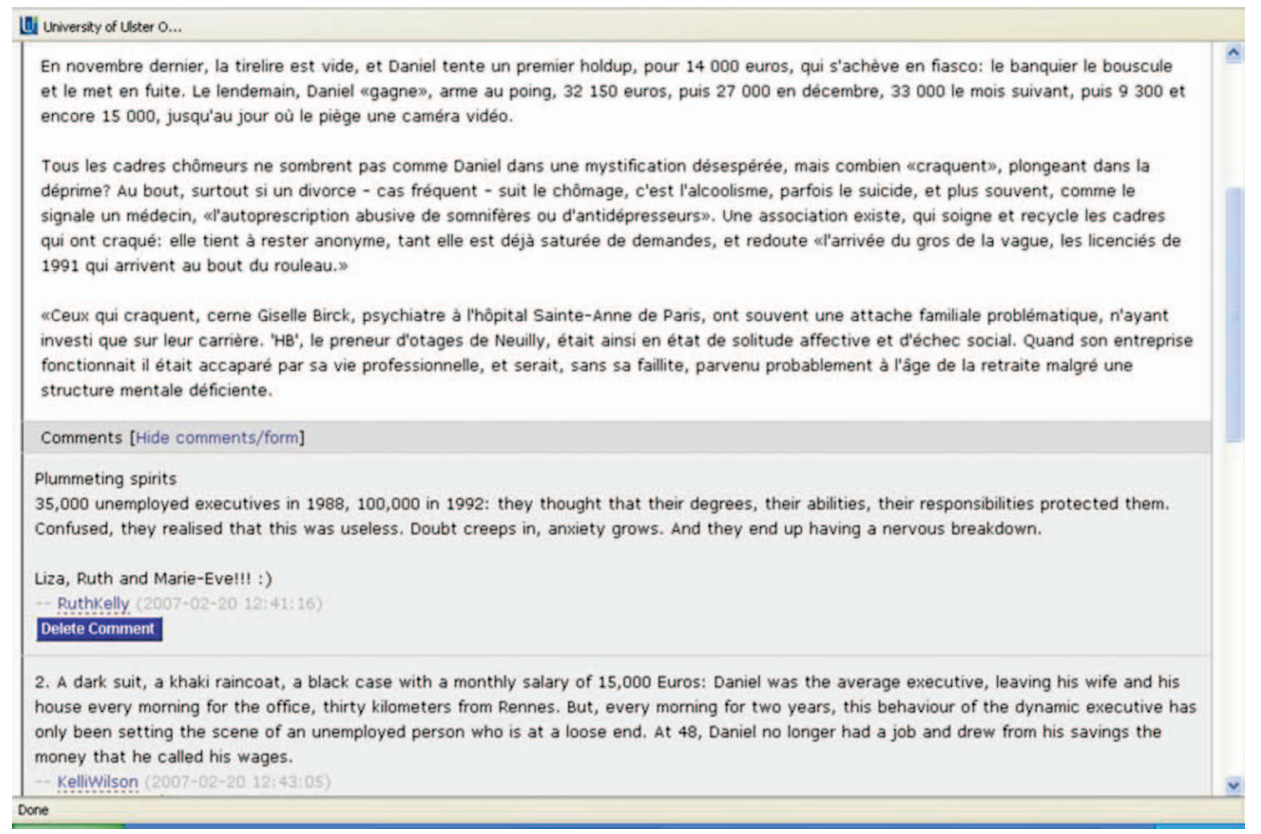

Figure 1. Translation wiki.

(2) Virtual learning environment - WebCT. In order to allow for variety in the activities undertaken, the wiki was not used every week. After three weeks using only the wiki, a new type of activity was introduced towards the middle of semester. Using an idea from TransIT Tiger and MetaText, the University's Virtual Learning Environment WebCT was used to create an electronic translation support facility. This area included copies of translations to be undertaken on alternate weeks in class. Within a dedicated area of WebCT, students had access to customised glossaries, specially-created to provide suggestions for translating key elements of vocabulary in the translation texts. In addition, in each translation, a number of key phrases and elements of vocabulary were hyperlinked. These links would provide contextual information or tips for translating the phrases. The area also provided students with access to newspaper articles on related themes in the target language to help them to identify ways of translating key vocabulary and phrases. Students would use this support facility collaboratively to prepare a translation that they would then upload to the wiki to allow for discussion at the end of the class. Although integrating the wiki into the activity might seem like a duplication of effort, the use of the translation support area on WebCT provided an additional bank of materials to help students prepare their translations and to demonstrate to the students the benefits of contextualising translation works as well as trawling through related texts for translation and lexical hints. Figure 2 gives an example of layout and resources available within the translation support area of WebCT. 


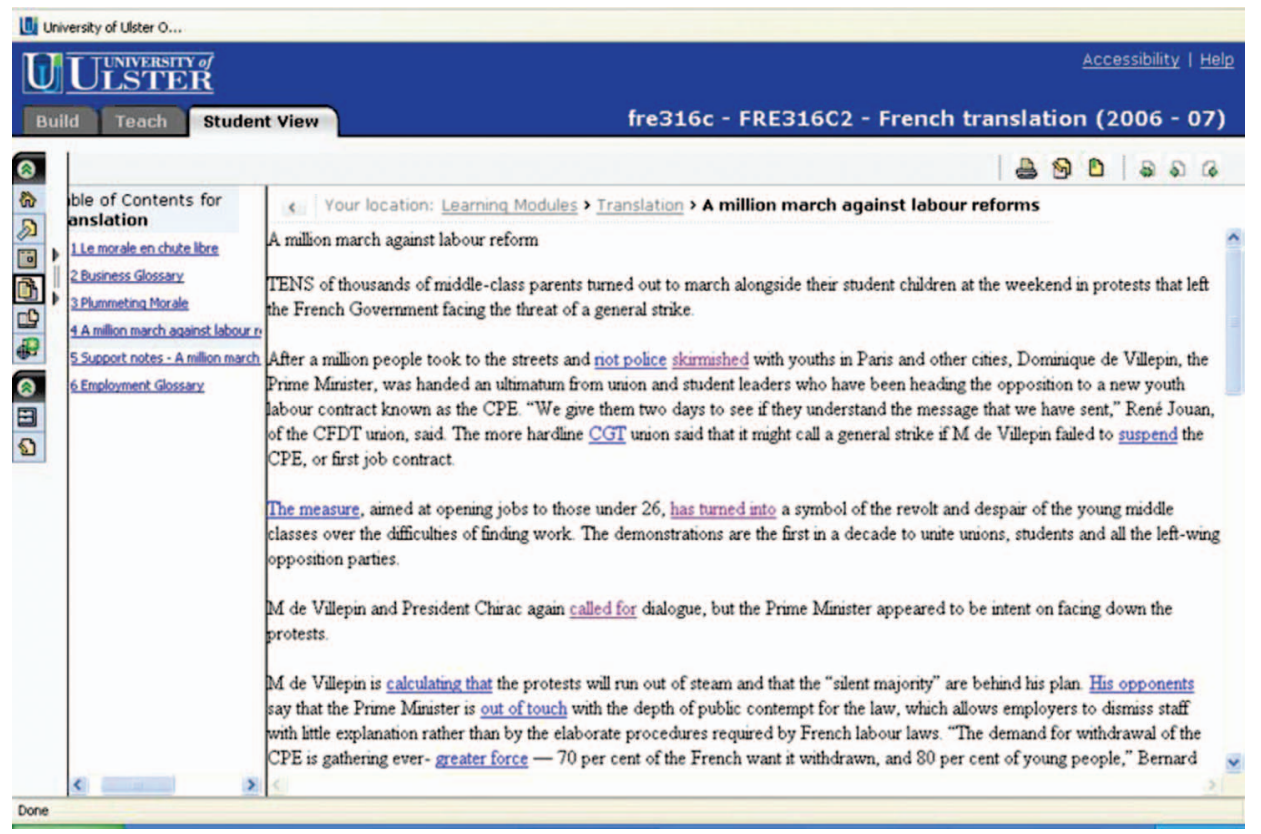

Figure 2. Electronic translation notebook on WebCT.

\section{Evaluation of courseware}

Student reaction to the project was gauged and measured in a number of ways: (1) weekly logs completed by students online after each class; (2) an end-of-semester evaluation questionnaire (Figure 3) and (3) observational analysis of classroom teaching and student reaction. By considering this data in relation to the three considerations for courseware integration that were established earlier in this article (learner expectations, practicality of fit and motivation), we can identify a number of important findings.

(1) Learner expectations - students feeling familiar with the technology

As we have seen earlier, it is important for students to feel they have mastered the technology in order to use it effectively in their learning. In the translation project undertaken at Ulster, the first week of class was used to familiarise students with the functionality of the wiki, electronic dictionaries and $W e b C T$ electronic notebook. A second form of training was provided by peers. Students were divided into groups of three not only to complete the translation work, but also to provide peer support for one another. Consequently, students would often ask others within the group if they had technical difficulties such as forgotten passwords. This principle follows Tharp and Gallimore's (1988, p. 185) model for effective learning, one stage is known as "assistance by more capable others", such as student peers. Thirdly, the monitoring functions available in the multimedia language lab allowed the tutor to identify when students were experiencing difficulties using the electronic tools during the course of the translation project. This was particularly useful if students had forgotten how to access the wiki, for example. 
1. How do you feel translation classes helped to develop your skills in the following areas:

a. Understanding difficult words and phrases / Developing your range of vocabulary

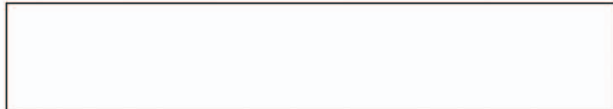

b. Learning how to translate overall meaning informal, literary contexts)

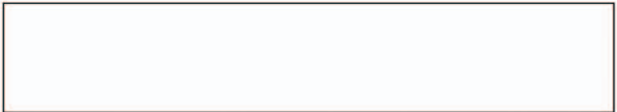

d. Acquiring transferable skills e.g. independent study, analytical reading.. multimedia lab did you find most useful? Please explain why.

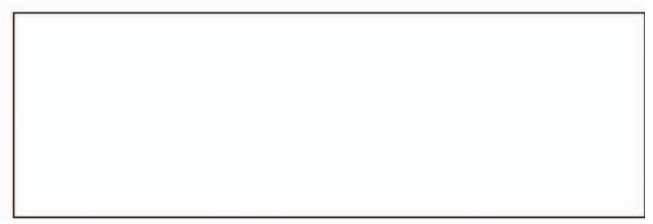

3. Which aspects of using computer technology in translation classes in the multimedia labs did you find least useful? Please explain why.

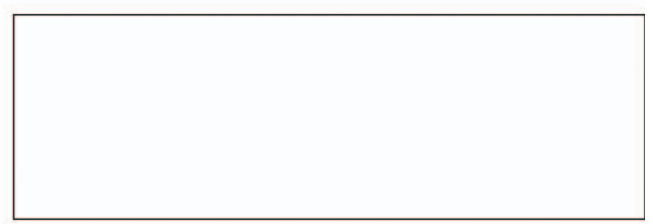

4. Which elements of classes in the multimedia labs could be improved? Please give practical suggestions for improving the classes.

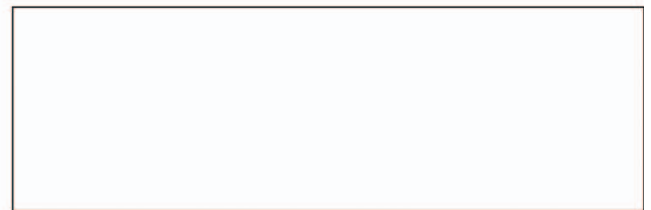

5. Please rate how you enjoyed multimedia translation classes overall (circling the number on the scale most appropriate, where 5 to 1, where 5 is very enjoyable and 1 is not enjoyable at all)

$\begin{array}{llll}4 & 3 & 2\end{array}$

Figure 3. End-of-semester evaluation questionnaire. 
Peer and tutor support during the project show the importance of sustained training. Initial induction was useful to familiarise students with the functionality of the tools being used but, inevitably over the course of the project, students would forget aspects that they had been shown in the induction. Furthermore, students would often raise different problems each week: one week, it would have been that some of them had forgotten their passwords, another week, some had forgotten how to access the electronic dictionaries. Given the different range of issues that would arise and that some groups would have more technical questions than others, students needed localised training throughout the project.

(2) Practicality of fit-access to resources

Clearly, a variety of factors will have influenced these results, such as group composition and external pressures (including differing at the beginning and end of semesters). It does seem clear, however that there is not conclusive evidence to suggest that student performance was enhanced by the technology. Despite that, however students did show considerable levels of motivation while engaging with the project.

Qualitative feedback from logs and questionnaires revealed that students were generally satisfied with the experience of using computer technology in translation class. The end-of-project questionnaire, which was not completed by all of the students involved in the project owning to timetabling issues, showed that those who were able to complete the questionnaire $(N=13)$ rated their multimedia translation classes as enjoyable or very enjoyable. In addition, if we look at the qualitative comments made by students in their questionnaire in response to the question: "which aspects of using computer technology in translation classes in the multimedia lab did you find most useful?" (Figure 3), we can identify a number of factors that have influenced motivation.

- Appreciation of pedagogical rationale. According to the qualitative questionnaire comments in Figure 4, we see that students had a general understanding of the pedagogical reasons, for using the wiki, for example, with at least three of them commenting that it allowed them to see other's translation on the screen at the same time.

- Value of accessible resources. Access to resources such as the electronic Oxford Hachette French dictionary were much lauded by students, not least because it allowed them to work in a completely computer-based environment. In fact, 7 out of 13 respondents (54\%) stated that they found

- "I felt that the class demonstrated the subtleties of the meaning of words. I began to see how the choice of word is not necessarily what it looks like in English"

- "Checking related websites helped me understand the context and get a feel for the language"

- "I found the Oxford dictionary very useful and the online dictionaries are very helpful"

- "Very helpful, I have realised it is important to look at different dictionaries to find the correct word to use."

- "Using the wiki was quite good too as you could see how everyone translated different pieces"

- "When we see the different translations people have made on the screen"

- "we were able to see everyone's versions/translations on our screen"

- "Use of WebCT in translation was useful to get translations and helpful tips"

Figure 4. Student comments. 
the electronic dictionary one of the most useful technological enhancements of the translation classes. In other words, students felt they had access to a range of facilities and resources from the relative comfort of a computer terminal.

- Variation of the medium. In their general comments, students remarked on the value of different aspects of the computer technology used. In Figure 3, we see that the wiki, $W e b C T$, electronic dictionary and websites (used for searching for texts related to the source translation) were all identified by different students as being highlights in the project. This suggests that the range of tools and resources used in the project were able to appeal to the different tastes and demands of students. This gives further weight to Warschauer's (1996, p. 20) conclusion that an amalgam of different computer-based approaches is necessary to achieve learning effectiveness.

(3) Motivation - seeing beyond the technology's shortcomings

According to Thornbury, Elder, Crowe, Bennett, and Belton (1996, p. 19), "students tend to fall back on what they know and seem to trust": they are not necessarily enthusiastic about using technology and levels of enthusiasm will vary from one cohort to the next. Equally, introducing too much technology can overwhelm students (Gillespie \& McKee, 1999, p. 41). The activities that the students undertook in the translation project followed a format that students were familiar with: working in groups on translations. The technology provided a platform for the students to not only engage with the traditional method of translation work that they had been used to, but also to interact with the enhancements that the technology was providing such as access to online articles containing similar vocabulary and online dictionaries. This might also explain why students seemed very positive about the experience of using computers in their translation class: there was less chance of culture shock. This is supported by feedback received from students through the end-of-semester questionnaire because students did not comment on issues like technical reliability. This is particularly significant since, during the course of project, students experienced frustrating technical difficulties such as computers restarting following the download of automatic updates and problems accessing networked drives occasionally being restricted. Given these difficulties, it was surprising that only one student (out of 13 respondents) commented on these technical problems as being a negative aspect to the project. In this context, we might assume that students were able to see that the benefits for using the technology in translation work (such as access to online dictionaries) outweighed the drawbacks from the students' perspective. This is supported by what Dörnyei (2001) describes as the third phase in the motivation process, namely the way in which students process their past experiences will determine the kind of activities they will be motivated to pursue in the future.

\section{Conclusion}

The findings of this research article suggest that the key considerations in evaluating the effectiveness of CALL, identified earlier, still remain key considerations in the embedding of computer technology into the student learning 
experience. This is particularly interesting as many of those aspects have remained unchanged for over 20 years even though the technology has changed beyond recognition in that time. The findings of this article, therefore, support the view of Felix (2008, p. 157), who believes that research in CALL can benefit from replication studies of previously-undertaken work because it can often reinforce the validity of that research. The research reveals a number of issues that might help future planning of projects that integrate computer technology in language learning.

\section{(1) The need for students to see the reasons for using technology}

There are a variety of reasons why students will want to use technology. In order to integrate courseware effectively into language learning and teaching, it would seem important to consider these reasons and to try to ensure that they can be facilitated by the courseware. As the example of this project showed, students could identify a range of other benefits, including enhanced access to resources, variation in the learning activities and an appreciation of the pedagogical reasons for using technology. It may seem to be stating the obvious, but if students do not see the benefits and possibly even consider that technology is being used for its own sake, there is a danger that they will either not engage with the technology effectively or may even come to resent it.

\section{(2) The need for comfort}

Although students are increasingly familiar with computer and other digital technologies in their daily life, this does not mean that they will embrace the use of technologies automatically in their learning. In fact, the trend is that they use what they find most familiar. Consequently, when designing computer-mediated learning activities, we need to be mindful of the need for a comfort zone. Students are already familiar with particular styles of learning (and teaching) and the introduction of technology into their learning environment is, in itself, quite a step. If we introduce the technology as well as a range of new learning activities that students may have never experienced before, this could be a step too far for many students and they may well simply not engage with the technology to enhance their learning as they feel overwhelmed. As a result, using computer technology as a way of facilitating familiar learning activities would seem to be an appropriate first step in the process of integrating computer technology into language learning activities. As students become more familiar and comfortable using the technology for their learning, more complex activities can follow.

\section{(3) What role does the technology play?}

As we have already seen, students tend to focus in on the reasons for using technologies. In planning our use of computer technology in learning and teaching, we might consider the reason for using computers to deliver it. Some of the reasons may include:

- Giving students flexible access to resources (such as dictionaries and websites). 
- Creating a learning artefact (such as a bank of translations that can be used for revision purposes or an activity that requires students to engage in web-based research).

- Enabling opportunities for tutors to monitor student progress (through classroom management software, for example).

- As a communication tool (such as the use of wikis and blogs to post comments and ideas for others to see and interact with).

\section{(4) Development of resources}

Creating resources and materials requires a considerable investment in time, effort and commitment and, more often than not, the work is undertaken in addition to teaching and other duties. In the case of the translation project outlined above, however, the development of resources and activities was undertaken by a member of staff who had a reduced teaching load, made possible by government funding.

Clearly, it is not always possibly for courseware to be developed in this way, however, the investment of time needed to develop resources and activities is considerable and this needs to be considered in the planning of any project that integrates computer technology into the student learning experience.

Perhaps most interestingly, one of the main conclusions we can draw from this investigation is that despite living in an increasingly digital age, integrating computer technology into language learning is not necessarily intuitive for students and we still need to consider a range of pedagogical and psychological factors in planning its use. A number of these such as the need for comfort and motivation as well as practical fit are well-established principles that still remain even in the age of digital natives.

\section{Notes on contributor}

David Barr is Head of School of Languages and Cultures at the University of Ulster, where he teaches French. He is a member of the Centre for Excellence in Multimedia Language Learning and has developed a range of web-based CALL materials. David is the UK representative for EUROCALL and regularly reviews for a number of CALL publications.

\section{References}

Barr, D. (2004). ICT - Integrating computers in teaching: Creating a computer-based languagelearning environment. Oxford, Bern, New York: Peter Lang.

Barr, D. (2008). Computer-enhanced grammar teaching. In F. Zhang \& B. Barber (Eds.). Handbook of computer-enhanced language acquisition and learning (pp. 101-113). New York: Information Science Reference.

Bennett, S., Manton, K., \& Kervin, L. (2007). The 'digital natives' debate: A critical review of the evidence. British Journal of Educational Technology, 39, 775-786.

Conole, G. (2008). The student perspective: The ever-changing landscape of technology use. $\operatorname{ReCALL}, 20,24-140$.

Cuban, L. (2001). Oversold and underused: Computers in the classroom. Cambridge, MA: Harvard University Press.

de los Arcos, B., Coleman, J., \& Hampel, R. (2009). Learners' anxiety in audiographic conferences: A discursive psychology approach to emotion talk. ReCALL, 21(1), 3-17.

Dörnyei, Z. (2001). New themes and approaches in second language motivation research. Annual Review of Applied Linguistics, 21, 43-59. 
Felix, U. (2008). The unreasonable effectiveness of CALL: What have we learned in two decades of research? ReCALL, 20, 141-157.

Fischer, G. (2001). User modelling in human-computer interaction. Journal of User Modelling and User-Adapted Interaction, 11(1/2), 65-86.

Fry, H., Ketteridge, S., \& Marshall, S. (1999). Understanding student learning'. In H. Fry, S. Ketteridge \& S. Marshall, (Eds.), A handbook for teaching \& learning in higher education: Enhancing academic practice (pp. 21-40). London: Kogan Page.

Gillespie, J. (2008). Mastering multimedia: Teaching languages through technology. ReCALL, $20,121-123$.

Gillespie, J.H., \& Barr, J.D. (2002). Reluctance, resistance and radicalism: A study of staff reaction towards the adoption of CALL/C\&IT in modern languages departments. $\operatorname{ReCALL}, 14(1), 129-141$.

Gillespie, J., \& McKee, J. (1999). Resistance to CALL: Degrees of student reluctance to use CALL and ICT. ReCALL, 11(1), 38-46.

Hawkins, E. (1981). Modern languages in the curriculum. Cambridge: Cambridge University Press.

Hubbard, P. (1988). An integrated framework for CALL Courseware Evaluation. CALICO Journal, 6, 51-72.

Jones, C. (1986). It is not so much the program, more what you do with it: The importance of methodology in CALL. System, 14, 171-178.

Leakey, J. (2011). Evaluating computer assisted language learning: An integrated approach to effectiveness research in CALL. Bern: Peter Lang.

Levy, M. (1997). Computer-based language learning: Context and conceptualization. Oxford: Clarendon.

Mazer, J., Murphy, R., \& Simonds, C. (2007). I'll see you on "Facebook": The effects of computer-mediated teacher self-disclosure on student motivation, affective learning, and classroom climate. Communication Education, 56(1), 1-17.

Munday, J. (2001). Introducing translation studies. London: Routledge.

Neumeier, P. (2005). A closer look at blended learning - Parameters for designing a blended learning environment for language teaching and learning. ReCALL, 17, 163178.

Newstead, S.E., \& Hoskins, S. (1999). Encouraging student motivation. In H. Fry, S. Ketteridge \& S. Marshall (Eds.), A handbook for teaching and learning in higher education (pp. 62-74). London: Kogan Page.

Nino, A. (2009). Machine translation in foreign language learning: language learners' and tutors' perceptions of its advantages and disadvantages. ReCALL, 21, 241-258.

Prensky, M. (2001). Digital natives, digital immigrants. On the Horizon, 9, 1-6. Retrieved 12 August 2009, from http://www.marcprensky.com/writing/Pren sky\%20-\%20Digital\%20Natives, $\% 20$ Digital $\% 20$ Immigrants $\% 20-\% 20$ Part $1 . p d f$.

Pym, A. (1992). Translation error analysis and the interface with language teaching. In C. Dollerup \& A. Loddegaard (Eds.), The teaching of translation (pp. 279-288). Amsterdam: John Benjamins.

Ryan, R., \& Deci, E. (2000). Self-determination theory and the facilitation of intrinsic motivation, social development and well-being. American Psychologist, 5(1), 68-78.

Scinicariello, S. (1997). 'Uniting teachers, learners, and machines: Language laboratories and other choices'. In M. Bush \& R. Terry (Eds.), Technology-enhanced language learning (pp. 185-213). Illinois: McGraw-Hill.

Stepp-Greany, J. (2002). Student perceptions on language learning in a technological environment: Implications for the new millennium. Language Learning and Technology, 6(1), 165-180.

Stracke, E. (2007). A road to understanding: A qualitative study into why learners drop out of a blended language learning (BLL) environment. ReCALL, 19(1), 57-78.

Talbot, G. (1996). Looking up in anger: Translation practice in the CALL lab. ReCALL, 8(1), $20-23$.

Tharp, R.G., \& Gallimore, R. (1988). Rousing minds to life. New York: Cambridge University Press.

Thornbury H., Elder, M., Crowe, D., Bennett, P., \& Belton, V. (1996). Suggestions for successful integration. Active Learning, 4, 18-23. 
Toner, G., Barr, D., Carvalho Martins, S., \& Wright, V. (2008). Multimedia language learning in higher education in the UK. University of Ulster. Retrieved 17 August 2009, from http:// www.cemll.ulster.ac.uk/downloads/survey\%20report.pdf

Ushida, E. (2005). The role of students attitudes and motivation in second language learning in online language courses. CALICO Journal, 23(1), 49-78.

Warschauer, M. (1996). Computer assisted language learning: An Introduction. In S. Fotos, Multimedia language teaching (pp. 3-20). Tokyo: Logos International.

Winke, P., \& Goertler, S. (2008). Did we forget someone? Students' computer access and literacy for CALL. CALICO Journal, 25, 482-509. 